\title{
NEW SPECIES OF ECONOMIC MITES
}

\author{
H. E. Ewing, Iowa State College, Ames, Ia.
}

In the following paper seven species of mites are described. Six of these species are injurious, some being quite serious pests, and one species is beneficial, being predaceous. Of the seven species described, six are new, and the remaining species, Tarsonemus pallidus Banks (?), may prove to be new in the future. This species, which is the one that seriously injures cyclamens, does not agree with Mr. Bank's descrip-. tion of pallidus, but probably is the species described by Banks, as specimens agree fairly well with material determined by Banks as $T$. pallidus.

\section{Tetranychus uniunguis n. sp.}

A greenish yellow species. Palpi rather stout, reaching the tip of tibia of leg $I$. Palpal claw rather short, strongly curved and not very sharp at its tip. Thumb of palpus atout, as broad as long, reaching, but not surpassing, the palpal claw; finger of thumb situated in the middle of the apex, about twice as long as broad, and rounded at its tip. Hairs of thumb distributed as follows; two small ones on the inside of thumb near its apex, one long hair, about as long as the thumb itself, on the inside near the base, and another of about equal length on top not far from the base. Cheliceræ each arising near the base of plate, and making an evenly rounded loop posteriorly, and then passing forward for about two-thirds their length, then in a downward direction to their tips. The only place that the cheliceræ are swollen is near their bases. Tarsus of leg I considerably longer than the tibia. Tarsi each ending in a single claw, which is not strongly curved, but is very sharp; two tenent hairs. Length, $0.59 \mathrm{~mm}$.; width, $0.42 \mathrm{~mm}$.

From Urbana, Illinois; on arbor vitae (Thuja occidentalis); by the writer.

\section{Tetranychus multidigituli n. sp.}

Preserved specimens yellowish. Body somewhat depressed, skin more or less wrinkled, and abdomen somewhat pointed behind. Palpi prominent; claw, strong and much curved; thumb stout, almost as broad as long, and not surpassing the claw; digit or finger about half as long as thumb and less than half as long as broad; digituli, or spines, at least five near the tip of thumb, setæalso present on thumb. Mandibles, or cheliceræ, slender, with a simple loop toward base, and of uniform diameter except at base where they are slightly swollen. A single pair of eyes present, placed laterally; cornea strongly curved. Abdomen clothed above with rather stout, simple, slightly curved setø. Legs moderate; tarsus of leg I about one and a third times as long as tibia, and truncate at its tip, from which springs a very long tactile seta. Tarsal claws rather weak, strongly curved near their bases, beyond which they are divided into six prongs. Onychium with four tenent hairs. Length, $0.30 \mathrm{~mm}$.; width, 0:21 mm.

From Wooster, Ohio; on bark of honey locust, Gleditsia triacanthos; by J. S. Houser. Several specimens. This species differs from most of the other species in the genus in having several digituli, or setæ, to 
tip of thumb; in having the setæ of the body relatively short and of about the same length, and in having the tip of the tarsi broad and truncate.

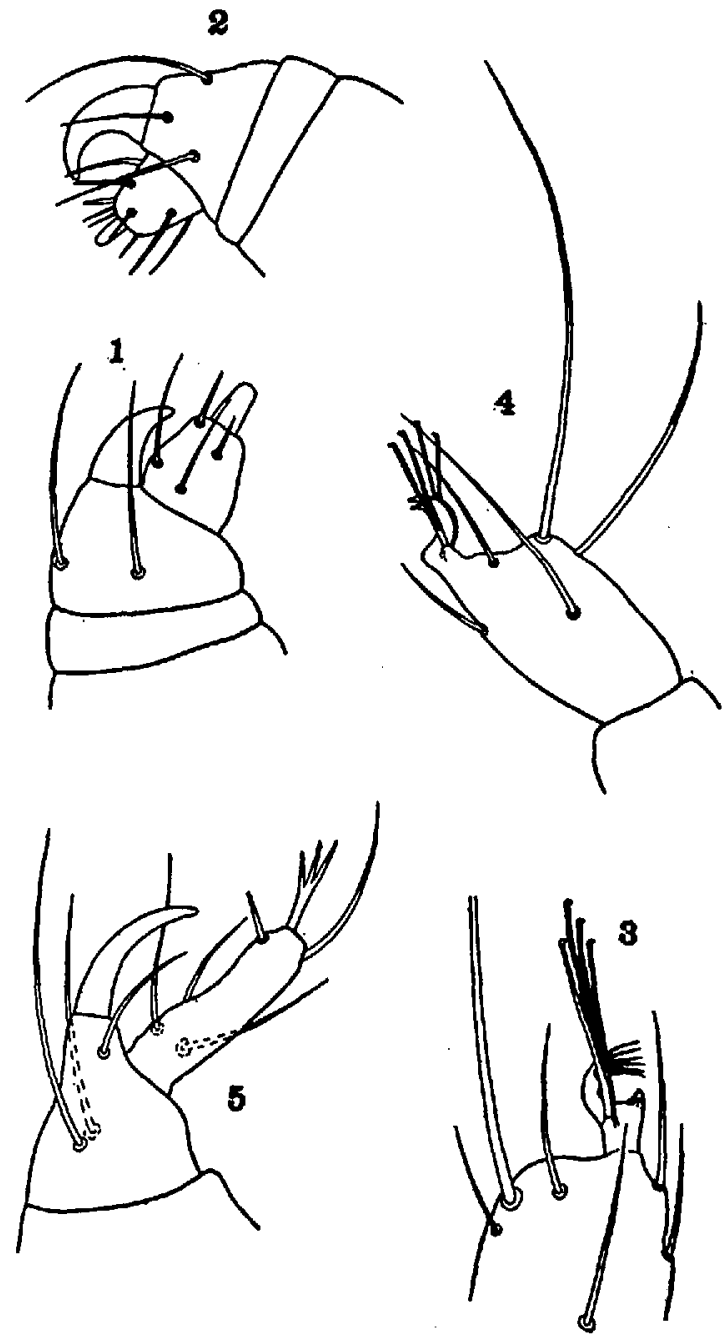

Fig. 25. 1, Tetranychus uniunguis $\mathrm{n}$. sp. Tip of left palpus from the inside; 2 , Tetranychus multidigituli n. sp. Tip of right palpus from the inside; 3, Tetranychus multidigituli $\mathrm{n}$. sp. Tip of tarsus showing claw and onychium; 4, Schizoletranychus latitarsus n. sp. Tarsus of leg I from the outside; 5, Caligonus mali n. sp. Left palpus from the inside.

Schizotetranychus latitarsus n. sp.

Preserved specimens yellowish and reddish with dark spots showing through the body wall. Cephalothorax fully as broad as long. Mandibular plate, or rostrum, over twice as long as broad. Apparently two eyes on each side of cephalothorax, 
but only one with a perfect cornea. Palpi prominent; palpal claw very short, stout, and but slightly hooked; thumb swollen, short, not reaching tip of claw, and apparently without digit. Abdomen rather strongly arched, and evenly rounded behind except for the anal papilla. Above, the abdomen is sparsely clothed with long, prominent, slightly curved, minutely pectinate setæ. Legs moderate; tarsus of leg I but slightly longer than tibia, very broad and truncate at its tip; at its tip above it bears a large tactile seta much longer than the tarsus itself. The tarsi of the legs are each provided distally with two subequal, simple claws, and four tenent hairs; of the latter the two inner are longer than the two outer, and all are at least twice as long as the claws. Length, $0.36 \mathrm{~mm}$; width, $0.23 \mathrm{~mm}$.

From Pasadena, California; on bamboo; by C.P.Clausen. Described from several specimens. This species is probably an introduced one.

\section{Caligonus mali n. sp.}

Preserved specimens yellowish and reddish, but live ones brighter with more red. Body oval, about twice as long as broad. Palpi long, reaching about the middle of tarsus I; terminal segment about as long as segment next to it, and ending in a long, downwardly curved, sharp, simple claw. Thumb of palpus cylindrical, slender, surpassing the claw by about one-fourth its length and bearing at its tip a prominent, straight spine, 3-partite at its tip and about one-half as long as the thumb itself, and just below this prominent spine a longer, curved simple seta. Cheliceræ with stout bases, but tapering rapidly toward the slender, sharp, needle-like distal portions. Tips of cheliceræ reach to the distal end of femur of palpus. Abdomen somewhat pointed toward apex, sparsely clothed above with practically straight simple setæ. Legs moderate; anterior pair slightly longer than the others; posterior pair extending for fully one-half their length beyond the tip of the abdomen. Each tarsus is armed distally with two equal claws, between which is a delicate onychium, or pulvillus, composed of a central, longitudinal part from which springs several slender, downwardly projecting seta-like elements. Length, $0.30 \mathrm{~mm}$; width, $0.16 \mathrm{~mm}$.

From Hillsboro, Oregon; causing a silvering of the leaves of the apple. The apple branches which the writer examined were badly infested and damaged by this mite. Serious injury to apple leaves was reported from Hillsboro, Oregon, in 1913.

\section{Hypoaspis armatus $\mathbf{n} . \mathbf{s p}$.}

Male.-A uniform, light yellowish-brown color. Body oval, almost evenly rounded behind. Epistome long and ending in two prominent spines or teeth. Cheliceræ very characteristically armed. At the tip of each there is a very prominent lateral, recurved, hook-like projection with a barb at its tip; below this is a sharp incurved hook, which crosses its mate from the opposite side; above is a reduced arm with a pectinate process dorsally and in front. Ventrally near the base of the armed part of the chelicera is a simple tubercle. Peritreme very slender, curved similar to the margin of the body next to which it lies. Abdomen clothed above with a few moderate, slightly pectinate setæ; the shoulder pair is especially prominent. At the anterior end of the abdomen near the median line is a pair of medium, simple setæ. Legs long; tarsus of leg I about one and a half times as long as the tibia and bearing a pair of weak claws at the tip of a very long pedicel; tibia of leg I fully twice as long as broad and broader distally than proximally; last pair of legs extending beyond the tip of abdomen. Length, $0.27 \mathrm{~mm}$; width, $0.17 \mathrm{~mm}$. 
From Whittier, California; on lemon leaves; by Mr. Neüls. The type specimen from Neüls shows the sperm sac attached to the tip of the cheliceræ. In the Gamasida, the male transfers the sperm from his genital orifice to the vulva of the female in a hyaline sac by means of the cheliceræ. The various modifications of the cheliceræ are frequently adaptations for this method of fertilization.

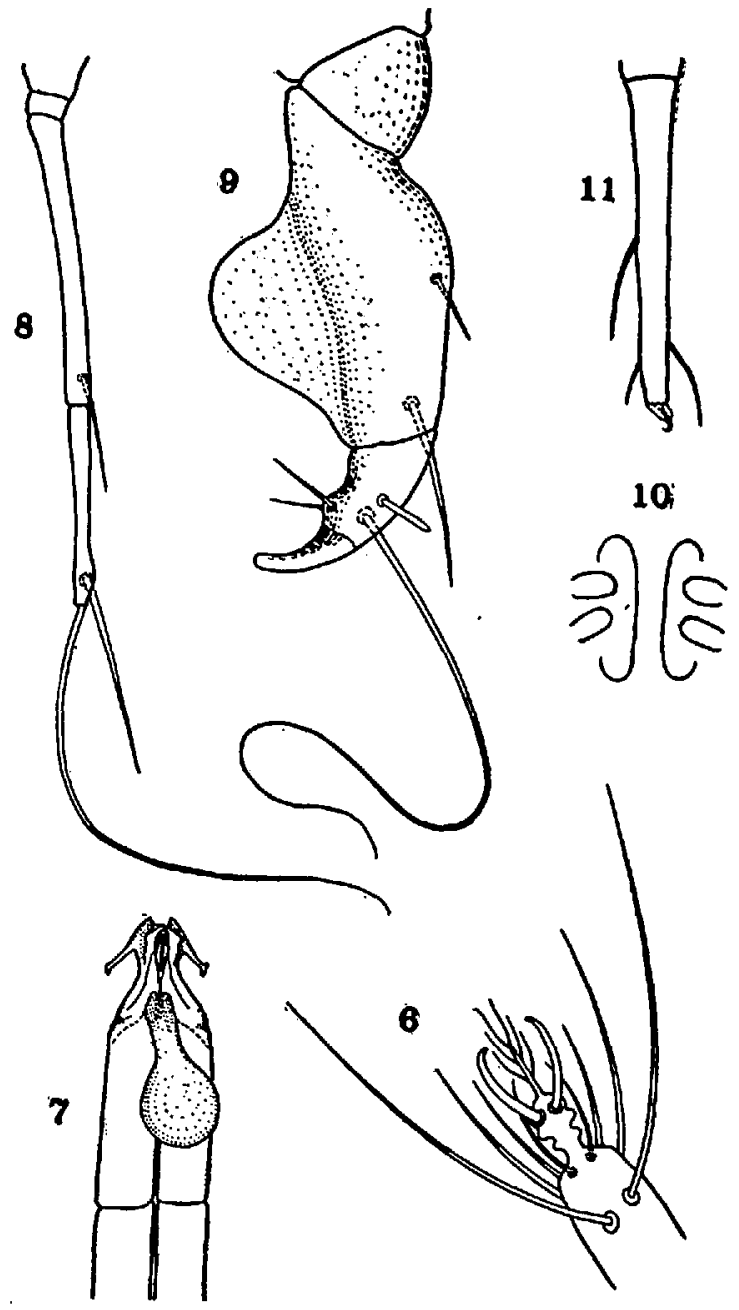

Fig. 26. 6,'Caligonus mali n. sp. Tip of tarsus of leg I from above; 7, Hypoaspis armatus $\mathrm{n}$. sp. Cheliceræ of male from below, showing the sperm sac adhering to the hooks near the tip; 8, Tarsonemus pallidus Banks (?) Left hind leg of female from below; 9, Tarsonemus pallidus Banks (?) Right hind leg of male, from above; 10, Monieziellabipunctata n.sp. Vulva; 11, Monieziella bipunctata n.sp. Tarsus of leg IV. 


\section{Tarsonemus pallidus Banks (?)}

Female.-Body pale yellowish-brown, capitulum darker. Total length of the body about twice that of its greatest width. Capitulum large, extending forward to about the middle of tarsus of leg $\mathbf{I}$. Pseudostigmatic, or sense, organs dorso-lateral, with spherical heads and very short pedicels, which arise from prominent circular pores. Just lateral to each sense organ is situated a very long tactile seta, which surpasses by fully a third of its length leg II, near which it is also situated. Abdomen more or less pointed posteriorly, and bearing along its posterior margin three pairs of small, inconspicuous setæ. Anterior pair of legs stout; second pair slightly smaller; third pair extending beyond the margin of abdomen by the full length of the tarsus and onehalf the length of the tibia. Posterior legs reaching the tip of abdomen; tarsus almost two-thirds as long as the tibia, and bearing at its tip a very long terminal seta, as long as the total length of leg IV; a short distance from its tip, on the outside, the tarsus bears a somewhat stouter seta, a little over a third as long as the terminal one. Length, $0.21 \mathrm{~mm}$; width, $0.12 \mathrm{~mm}$.

Male.-Body stout, legs short. Capitulum reaching the tips of anterior legs. Lateral spine at junction of cephalothorax with abdomen about one-half as long as leg II. Leg IV very characteristic, segment II about two-thirds as long as the entire leg, curved, with a large, hyaline, blade-like expansion on the inside which is almost as broad as the segment proper and extends for about the distal two-thirds of the segment; below near its tip segment II bears a long seta. Segment III of leg IV short, much curved, bearing below near its tip a very long seta, which is equal in length to the entire leg; on the outside there is a short seta, and a more or less spine-like one on the inside at the tip. Distal claw long, curved, but tip not sharpened. Length, $0.13 \mathrm{~mm}$. width, $0.09 \mathrm{~mm}$.

From Corvallis, Oregon; on cyclamen; by G. F. Moznette. Described from several specimens. According to $\mathrm{Mr}$. Moznette this species causes serious injury to the cyclamen plant.

\section{Monieziella bipunctata n. sp.}

Alcoholic specimens pale yellowish, with the lateral abdominal maculations a chestnut brown. Cheliceræ large, stout. Cephalothorax more or less triangular in shape; anterior bristles prominent, slightly surpassing the mandibles; posterior bristles equal to about one-half the total length of the body, and each situated about one-half the distance from the median line to the lateral margin of the body. Abdomen separated from the cephalothorax by a transverse almost straight line. Shoulder bristles small, inconspicuous. At its tip the abdomen bears a pair of very long setæe. They are about as long as the width of the abdomen itself. Legs moderate; anterior pair extending beyond the tips of the cheliceræ by about a third of their length. Tarsus of leg I about twice as long as the tibia with a rather stout seta above about one-third the length of the segment from its base, a slender tactile seta above near tip, and a rather long seta ventrally near the base. Length, $0.22 \mathrm{~mm}$; width, 0.12 mm.

From Oregon; on base of buds of filbert; by A. L. Lovett. Many specimens. 